\title{
Increasing Efficiency and Reducing Costs of Citrus Nutritional Programs ${ }^{1}$
}

Mongi Zekri, Thomas Obreza and Arnold Schumann²

To maintain a viable citrus industry, Florida growers must consistently produce large, high quality, economic fruit crops from year to year. Efficiently producing maximum yields of high quality fruit is difficult without an understanding of soils and nutrient requirements of bearing citrus trees. Most Florida citrus is grown on soils inherently low in fertility with low cation exchange capacity (CEC) and low water-holding capacity, thus they are unable to retain sufficient quantities of available plant nutrients against leaching by rainfall or excessive irrigation.

\section{Nitrogen and Potassium}

Nitrogen $(\mathrm{N})$ and potassium $(\mathrm{K})$ are the two most important nutrients applied as fertilizer in Florida citrus groves. Nitrogen influences vegetative growth, flowering, and fruit yield more than any other nutrient. Potassium plays a key nutritional role in determining yield, fruit size, and quality. Fertilizer application ratios of $\mathrm{N}$ to $\mathrm{K}$ are usually $1: 1$, but a ratio of 1:1.25 may be useful on high $\mathrm{pH}$ or calcareous soils if $\mathrm{K}$ is low in the tree.
Management practices that improve fertilizer efficiency include:

- checking leaf analysis results for nutritional deficiencies or excesses,

- basing $\mathrm{N}$ fertilizer rates on IFAS recommendations and expected production (Tables 1, 2, and 3),

- selecting fertilizer formulations appropriate for existing conditions,

- carefully placing fertilizer within the root zone,

- timing applications to avoid the rainy season,

- splitting applications, and

- irrigating to meet the needs of the tree while minimizing leaching.

\section{Leaf Analysis}

Leaf sampling and analysis is a useful management tool for making fertilization decisions. One indicator of successful fertilizer management is a citrus tree with leaf nutritional standards within

1. This document is Fact Sheet SL222, a fact sheet of the Soil and Water Science Department, Florida Cooperative Extension Service, Institute of Food and Agricultural Sciences, University of Florida. Original publication date January 2005. Visit the EDIS Web Site at http://edis.ifas.ufl.edu.

2. Mongi Zekri, Citrus Extension Agent IV, Hendry County Extension Office, LaBelle; Thomas Obreza, Professor, Soil and Water Science Department, Gainesville; and Arnold Schumann, Assistant Professor, Citrus Research and Education Center, Lake Alfred; Florida Cooperative Extension Service, Institute of Food and Agricultural Sciences, University of Florida, Gainesville, FL 32611-0290. 
optimum ranges (Table 4). Trends of leaf $\mathrm{N}$ and $\mathrm{K}$ results over several years provide the best criteria for adjusting rates within the recommended ranges. Soil analysis is useful to determine soil $\mathrm{pH}$ and extractable phosphorus, calcium, and magnesium. Current Florida soil test interpretations for a variety of crops including citrus are presented in Table 5.

\section{Recommended Fertilizer Rates}

Numerous $\mathrm{N}$ fertilizer rate and timing studies conducted by University of Florida and USDA-ARS scientists for many years on a wide range of soil types, tree ages, varieties, rootstocks, and cultural conditions have verified that $\mathrm{N}$ rates in excess of 200 to $240 \mathrm{lbs} /$ acre are not justified except for unusually productive groves (e.g. $>700$ boxes/acre for round oranges). Excessive rates of $\mathrm{N}$ can reduce yields and fruit size.

\section{Grove Conditions}

In a mature grove where there is little net increase in tree size, $\mathrm{N}$ used for leaf growth is largely recycled as leaves fall, decompose, and mineralize. Replacing $\mathrm{N}$ removed by fruit harvest becomes the main focus of fertilization, and nutrient requirements should vary as the crop load changes. Nutritional programs should also be adjusted when leaf or tree canopy loss occurs due to severe pruning or freezes, or if extensive root damage occurs following flooding, tropical storms, or hurricanes. In the case where leaves and fruit have been lost but the root system remains intact, fertilizer rates may need to be elevated to support the growth of replacement leaves and fruit. If roots and canopy both suffer damage, fertilizer rates should be reduced proportionally to the amount of canopy loss. With the reduction in rates, application frequency should be increased.

Inorganic and synthetic organic $\mathrm{N}$ fertilizers are high-analysis materials and are generally most economical for use in citrus groves. They are rapidly available unless formulated as a controlled-release product. The use of high analysis fertilizers almost eliminates the need for filler, so a substantial portion of the mixing, transportation, and application cost is reduced. Loss of $\mathrm{N}$ through ammonia volatilization on calcareous soils is a concern when ammoniacal-N is applied to the soil surface without being incorporated by rainfall or irrigation. The use of controlled-release fertilizers for resets in established groves is a viable option.

\section{Applying Fertilizer}

Two-thirds of the fertilizer applications to citrus each year should occur between January and early June, timed so that nutrients are available during the flowering and fruit-setting period. The remaining one-third can be applied in September or October. Split fertilizer applications or fertigation combined with sound irrigation management increase fertilizer efficiency by consistently supplying nutrients and by reducing leaching if unexpected rain occurs. With these circumstances, less fertilizer is required. Fertilizer reduction can also be realized by targeted placement within the root zone, timing applications to avoid rainy periods.

When fertigating, nutrients are placed in the wetted area where feeder roots are extensive. The fertilizer can be applied frequently in smaller amounts so it is available when the tree needs it. Thus, application costs are lowered when compared with dry or foliar fertilizers. Efficiency and cost savings of fertigation are greatest for young trees. Fertigation is not a recommended production practice if the irrigation system is non-uniform or poorly designed. Remember that fertilizer and water are wasted when a calendar-based fertigation schedule applies nutrients to very wet soil. Water and nutrient uptake are drastically reduced under saturated soil conditions.

Nutrient uptake is enhanced by foliar feeding when a soil is calcareous or possesses any other condition that decreases a tree's ability to take up nutrients. Foliar applications of low-biuret urea (25 to $28 \mathrm{lbs}$ N/acre) or phosphorous acid (2.6 quarts/acre of 26 to $28 \% \mathrm{P}_{2} \mathrm{O}_{5}$ material) in late December or early January are known to increase flowering, fruit set, and fruit yield. Post-bloom foliar applications of potassium nitrate or mono-potassium phosphate ( 8 lbs/acre $\mathrm{K}_{2} \mathrm{O}$ ) in late April have been found to increase fruit size and yield. 


\section{Phosphorus}

Phosphorus (P) applied to citrus groves during establishment and early growth stages does not leach significantly, but rather $\mathrm{P}$ accumulates in the soil where it becomes slowly available. Consequently, fertilizer applications containing $\mathrm{P}$ can be reduced or omitted in mature groves. Phosphorus does not leach readily when the soil $\mathrm{pH}$ is 6 or higher, and the fruit crop removes very little $\mathrm{P}$. Therefore, regular $\mathrm{P}$ fertilizer applications are not necessary. Some soils used for new citrus plantings may be naturally low in P--for example the commonly known "sand-soaked" areas. In this situation, $\mathrm{P}$ fertilizer should be applied, but only until soil tests show it is no longer necessary.

\section{Micronutrients}

The use of most micronutrients is recommended only when deficiency symptoms persist. Copper should not be included in the fertilizer if copper fungicides are used or if a soil test shows sufficient copper is present (5 to $10 \mathrm{lbs} / \mathrm{acre}$ ). Molybdenum deficiency occurs on soils that have become very acidic, and can serve as an indicator of potential problems with aluminum toxicity. A lime application will raise soil $\mathrm{pH}$ and usually corrects this problem. Iron deficiency can be corrected by applying an $\mathrm{Fe}$ chelate, for example Fe-EDTA where soil $\mathrm{pH}<7$ and Fe-EDDHA where soil $\mathrm{pH}>7$. Foliar spray applications of micronutrients (manganese, zinc, copper, boron, and molybdenum) are much more effective and economically practical than soil applications. These micronutrients should be included with post-bloom or summer foliar sprays after full leaf expansion of the new growth flush.

\section{Soil pH}

Targeted soil pH should be between 5.5 and 6.5. Soils high in copper should be maintained at the high end of the range. A distinct advantage of $\mathrm{pH} 6$ compared with $\mathrm{pH} 5$ has been demonstrated in several studies, and $\mathrm{pH}$ of 7 was no better than 6. Soil pH can be increased by application of either calcitic or dolomitic lime. Dolomite supplies both calcium and magnesium, so the choice of dolomite would be more advantageous if magnesium is also necessary. Liming a soil that has a $\mathrm{pH}$ of 6 or greater is costly and unnecessary. In groves where soils have a favorable $\mathrm{pH}$ but a soil test or leaf analysis indicates low calcium, gypsum (calcium sulfate) can be applied as a source of calcium that will not affect soil $\mathrm{pH}$.

Applying dolomite as a source of magnesium is not a recommended practice if the soil $\mathrm{pH}$ is in the desired range. Under these conditions, soil application of magnesium sulfate or foliar application of magnesium nitrate are effective for correcting magnesium deficiency.

\section{Key points summarized}

- Increasing the efficiency of applied nutrients is a key to economic citrus production.

- Nitrogen and potassium fertilizers affect fruit production and quality more than any other applied nutrients.

- Management practices that improve fertilizer efficiency include:

1. Using leaf and soil analysis to guide fertilization programs.

2. Choosing realistic fertilizer rates based on established guidelines and expected production.

3. Selecting fertilizer sources appropriate for grove conditions.

4. Careful placement and timing of fertilizer applications.

5. Managing irrigation to minimize leaching of soluble nutrients.

- Foliar feeding is appropriate when soil conditions prevent sufficient uptake of nutrients to meet tree demands.

- Phosphorus fertilizer should be applied judiciously because $\mathrm{P}$ can accumulate in the soil.

- Micronutrients should be applied only when deficiency symptoms persist. 
- Keep soil pH in the range of 5.5 to 6.5. Do not overlime. 
Table 1. Current UF/IFAS-recommended $\mathrm{N}$ fertilizer rates for citrus.

\begin{tabular}{|c|c|c|c|c|c|}
\hline $\begin{array}{l}\text { Year in } \\
\text { Grove }\end{array}$ & Oranges & Grapefruit & Tangerines & Murcotts & Other \\
\hline \multicolumn{6}{|c|}{ 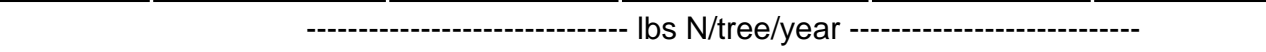 } \\
\hline 1 & $0.15-0.30$ & same & same & same & same \\
\hline 2 & $0.30-0.60$ & same & same & same & same \\
\hline 3 & $0.45-0.90$ & same & same & same & same \\
\hline \multicolumn{6}{|c|}{ 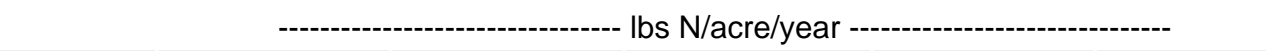 } \\
\hline \multirow[t]{2}{*}{$4+$} & $120-200$ & $120-160$ & \multirow[t]{2}{*}{$120-250$} & \multirow[t]{2}{*}{$120-300$} & \multirow[t]{2}{*}{$120-200$} \\
\hline & $120-200^{A}$ & $120-210^{A}$ & & & \\
\hline
\end{tabular}

Table 2. Average amounts of various nutrients contained within 100 boxes of Hamlin oranges. ${ }^{A}$

\begin{tabular}{|lc|}
\hline \hline Nutrient & Ibs of nutrient per $\mathbf{1 0 0}$ boxes $\mathbf{9 0}$ lbs/box) of fruit \\
\hline $\mathrm{N}$ & 12.5 \\
$\mathrm{P}$ & 1.4 \\
$\mathrm{~K}$ & 17.6 \\
$\mathrm{Ca}$ & 4.5 \\
$\mathrm{Mg}$ & 1.9 \\
$\mathrm{~S}$ & 1.1 \\
$\mathrm{Fe}$ & 0.024 \\
$\mathrm{~B}$ & 0.020 \\
$\mathrm{Zn}$ & 0.020 \\
$\mathrm{Mn}$ & 0.011 \\
$\mathrm{Cu}$ & 0.006 \\
\hline $\mathrm{A} A$. K. Alva, unpublished data. \\
\hline \hline
\end{tabular}

Table 3. Average amounts of various nutrients contained within 100 boxes of four citrus varieties. ${ }^{A}$

\begin{tabular}{|c|c|c|c|c|}
\hline Nutrient & Hamlin & Parson Brown & Valencia & Sunburst \\
\hline & \multicolumn{4}{|c|}{------- lbs of nutrient per 100 boxes $^{\mathrm{B}}$ of fruit --------- } \\
\hline $\mathrm{N}$ & 10.6 & 11.2 & 13.3 & 13.5 \\
\hline$P$ & 1.5 & 1.5 & 2.0 & 1.8 \\
\hline $\mathrm{K}$ & 13.5 & 13.2 & 14.3 & 13.9 \\
\hline $\mathrm{Ca}$ & 4.0 & 4.9 & 4.3 & 3.3 \\
\hline $\mathrm{Mg}$ & 1.1 & 1.2 & 1.2 & 1.0 \\
\hline $\mathrm{Fe}$ & 0.02 & 0.03 & 0.07 & 0.04 \\
\hline $\mathrm{Mn}$ & 0.02 & 0.02 & 0.02 & 0.02 \\
\hline $\mathrm{Zn}$ & 0.03 & 0.03 & 0.03 & 0.04 \\
\hline $\mathrm{Cu}$ & 0.005 & 0.006 & 0.007 & 0.007 \\
\hline
\end{tabular}


Table 3. Average amounts of various nutrients contained within 100 boxes of four citrus varieties. ${ }^{A}$

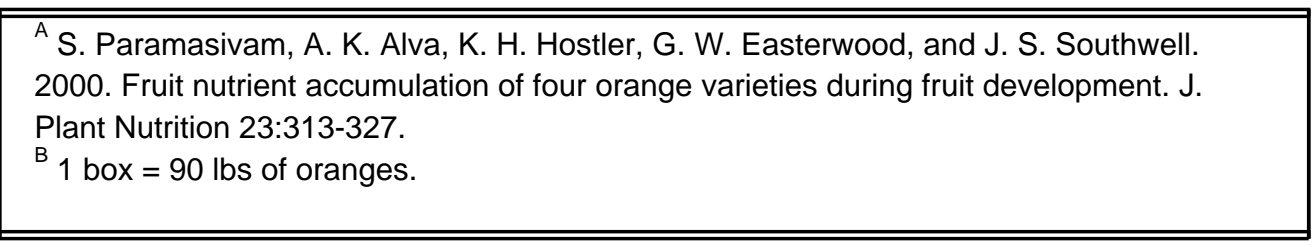

Table 4. Standard table for assessing nutritional status and adjusting fertilizer programs for citrus: Leaf analysis standard for assessing current nutrient status of citrus trees based on concentration of mineral elements in 4- to 6-month-old-spring-cycle leaves from non-fruiting terminals.

\begin{tabular}{|c|c|c|c|c|c|}
\hline Element & $\begin{array}{l}\text { Deficient } \\
\text { less than }\end{array}$ & Low & Satisfactory & High & $\begin{array}{c}\text { Excess } \\
\text { more than }\end{array}$ \\
\hline Nitrogen $(\mathrm{N})(\%)$ & 2.2 & $2.2-2.4$ & $2.5-2.8$ & $2.9-3.2$ & 3.3 \\
\hline Phosphorus (P) (\%) & 0.09 & $0.09-0.11$ & $0.12-0.17$ & $0.18-0.29$ & 0.30 \\
\hline Potassium (K) (\%) & 0.7 & $0.7-1.1$ & $1.2-1.7$ & $1.8-2.3$ & 2.4 \\
\hline Calcium (Ca) (\%) & 1.5 & $1.5-2.9$ & $3.0-5.0$ & $5.1-6.9$ & 7.0 \\
\hline Magnesium (Mg) (\%) & 0.20 & $0.20-0.29$ & $0.30-0.50$ & $0.51-0.70$ & 0.80 \\
\hline Sulfur (S) (\%) & 0.14 & $0.14-0.19$ & $0.20-0.40$ & $0.41-0.60$ & 0.60 \\
\hline Chlorine $(\mathrm{Cl})(\%)$ & ------ & ----- & $<0.5$ & $0.5-0.7$ & 0.7 \\
\hline Sodium (Na) (\%) & ------ & ------ & $<0.2$ & $0.2-0.5$ & 0.5 \\
\hline Iron (Fe) (ppm) & 35 & $35-59$ & $60-120$ & $121-200$ & 250 \\
\hline Boron (B) (ppm) & 20 & $20-35$ & $36-100$ & $101-200$ & 250 \\
\hline Manganese $(\mathrm{Mn})(\mathrm{ppm})$ & 18 & $18-24$ & $25-100$ & $101-300$ & 500 \\
\hline Zinc (Zn) (ppm) & 18 & $18-24$ & $25-100$ & $101-300$ & 300 \\
\hline Copper (Cu) (ppm) & 4 & $4-5$ & $6-16$ & $17-20$ & 20 \\
\hline Molybdenum (Mo) (ppm) & 0.06 & $0.06-0.09$ & $0.1-1.0$ & $2-50$ & 50 \\
\hline
\end{tabular}

Table 5. Current Mehlich 1 (double-acid) soil test interpretation for Florida citrus on mineral soils.

\begin{tabular}{|c|c|c|c|c|c|}
\hline Element & Very Low & Low & Medium & High & Very High \\
\hline & \multicolumn{5}{|c|}{ 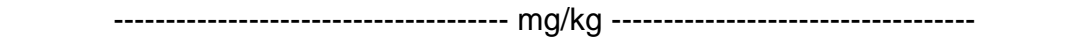 } \\
\hline Phosphorus (P) & $<10$ & $10-15$ & $16-30$ & $31-60$ & $>60$ \\
\hline Potassium (K) & $<20$ & $20-35$ & $36-60$ & $61-125$ & $>125$ \\
\hline Magnesium (Mg) & & $<16$ & $16-30$ & $>30$ & \\
\hline Calcium (Ca) & & & $150-250$ & & \\
\hline
\end{tabular}

